\title{
Enhanced boron removal by electricity generation in a microbial fuel cell
}

\author{
Qingyun Ping ${ }^{\mathrm{a}}$, Ibrahim M. Abu-Reesh ${ }^{\mathrm{b}}$, Zhen $\mathrm{He}^{\mathrm{a}, *}$ \\ ${ }^{a}$ Department of Civil and Environmental Engineering, Virginia Polytechnic Institute and State University, Blacksburg, VA 24061, USA \\ ${ }^{\mathrm{b}}$ Department of Chemical Engineering, College of Engineering, Qatar University, P.O. Box 2713, Doha, Qatar
}

\section{H I G H L I G H T S}

- For the first time, microbial fuel cells can be used to effectively remove boron.

- Such removal takes advantage of high $\mathrm{pH}$ generated from cathode reduction reaction.

- Electricity-driven removal has greatly enhanced the boron removal rate.

- Conductivity reduction during boron removal will help with further desalination.

\section{A R T I C L E I N F O}

\section{Article history:}

Received 31 March 2016

Received in revised form 16 July 2016

Accepted 22 July 2016

Available online $\mathrm{xxxx}$

\section{Keywords:}

Microbial fuel cells

Boron removal

Desalination

Seawater

Brackish water

Electricity

\section{GRA P H I C A L A B S T R A C T}

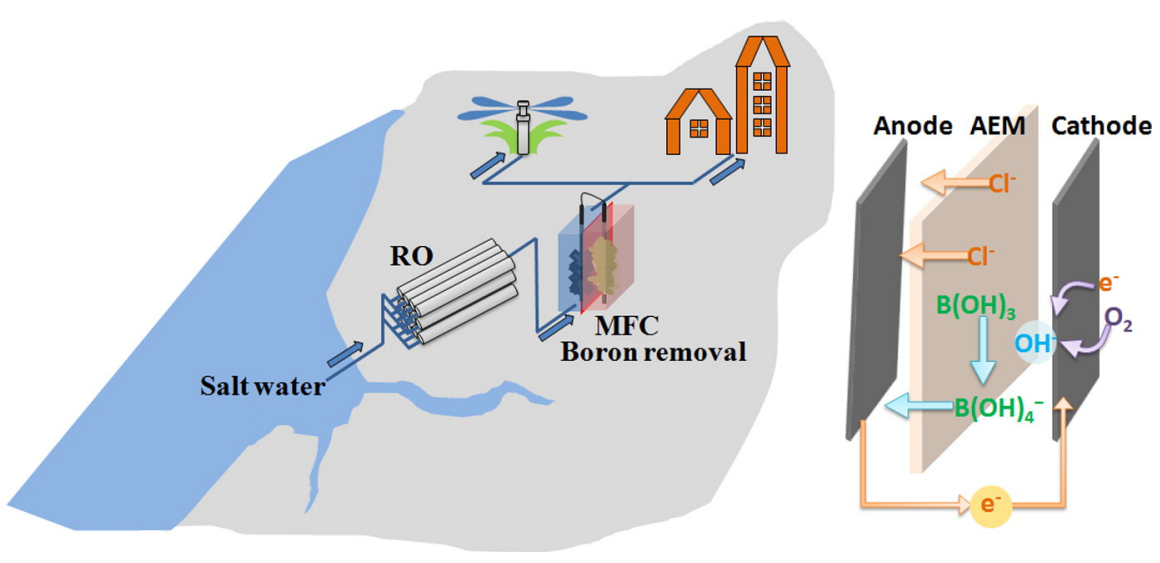

\begin{abstract}
A B S T R A C T
Boron needs to be removed during desalination, because excessive boron in the product water for irrigation can deteriorate plant growth. In this study, a microbial fuel cell (MFC) equipped with anion exchange membrane (AEM) was proposed and investigated to remove boron via two successive steps: boric acid is ionized to borate ions in the presence of high $\mathrm{pH}$ as a result of cathode reaction, and borate ions are transported across AEM driven by electricity generation. Two scenarios were examined, the MFC as a pretreatment process and the MFC as a post-treatment step in connection with conventional desalination. In the pretreatment mode, the MFC achieved $40-50 \%$ boron removal and the high $\mathrm{pH}$ condition could benefit downstream desalination or other methods for further boron removal. In the post-treatment mode, the MFC removed $80-90 \%$ of boron and decreased the boron concentration from 20 to $2 \mathrm{mg} \mathrm{L}^{-1}$ or from 5 to $1 \mathrm{mg} \mathrm{L}^{-1}$, which meets the irrigation water requirement. The removal rate in this MFC was much higher than that of a previously reported microbial desalination cell coupled with Donnan Dialysis system. Those results have demonstrated the potential of using MFCs for boron removal with benefits of conductivity reduction and electricity generation.

(c) 2016 Elsevier B.V. All rights reserved.
\end{abstract}

\footnotetext{
* Corresponding author.

E-mail address: zhenhe@vt.edu (Z. He).
}

\section{Introduction}

Desalination of seawater or brackish water has become an important process to obtain clean water worldwide due to the limited freshwater sources [1]. One of the problems for desalination is the remaining trace elements in the product water, such as boron. Boron exists in natural 
water in the form of boric acid, which is a non-dissociable compound. Seawater usually has a boron concentration of $\sim 5 \mathrm{mg} \mathrm{L}^{-1}$, while brackish water contains boron up to $40 \mathrm{mg} \mathrm{L}^{-1}$ [2]. Despite the fact that boron is an essential element for plant growth, when its concentration in the irrigation water exceeds $2 \mathrm{mg} \mathrm{L}^{-1}$, many plants would exhibit toxicity symptoms [3]. Boron can also be detrimental to animals and humans when being exposed to excessively. The World Health Organization (WHO) recommends the boron limit in drinking water to be as low as $0.5 \mathrm{mg} \mathrm{L}^{-1}$, while the Drinking-Water Quality Committee revised the boron guideline value to $2.4 \mathrm{mg} \mathrm{L}^{-1}$ in 2011 [4].

Although conventional reverse osmosis (RO) technologies can remove anions and cations at almost $100 \%$ rejection rate, the rejection of boron by RO in the uncharged form, boric acid, is low at 70\% [5]. The low-pressure brackish water RO membranes may have the boron rejection as low as 40\% [6]. To ensure adequate removal of boron from permeate, it will be necessary to raise the $\mathrm{pH}$ of the feed solution above the pKa value of 9.14 where the dominant boron is transformed to charged borate species (Eq. (1)) [4,7]. Other methods such as electrodialysis and electro-flocculation also require high $\mathrm{pH}$ to ionize boric acid to the charged form - borate [8-10]. The need for high $\mathrm{pH}$ in the feed solution will increase the consumption of chemicals such as sodium hydroxide, resulting in higher operating costs [3].

$\mathrm{B}(\mathrm{OH})_{3}+\mathrm{H}_{2} \mathrm{O} \Leftrightarrow \mathrm{B}(\mathrm{OH})_{4}^{-}+\mathrm{H}^{+}$

Elevation of $\mathrm{pH}$ is a phenomenon in the cathode of bioelectrochemical systems (BES) as a result of reduction reactions. BESs are emerging technologies that can convert chemical energy stored in wastewater directly into electrical energy with the help of microorganisms [11,12]. They have been demonstrated to efficiently remove organics from wastewater in the anode compartment of microbial fuel cells (MFCs) [13], desalinate seawater or brackish water in microbial desalination cells (MDCs) [14,15], produce hydrogen gas on the cathode of microbial electrolysis cells (MECs) with reduced external power supply [16], or conduct groundwater remediation [1719]. Under an anoxic condition, the anodic microorganisms release electrons while oxidizing organic matters and then transfer the electrons from inside the cells to the anode resulting in a negative anode potential [20]. The reduction of a terminal electron acceptor such as oxygen on the cathode is driven to produce hydroxide ions (Eq. (2)) and complete the electric circuit [21]. This feature of the cathode was employed in a previous study that accomplished boron removal by a system coupling MDCs with Donnan Dialysis (DD) [22]. Although the coupled system achieved effective boron removal, the higher mobility of hydroxide ions over borate ions in the MDC resulted in loss of hydroxide ions from the desalination compartment into the anode compartment and those hydroxide ions outcompeted borate ions, thereby limiting the removal efficiency. The DD as post-treatment proved to have the most effective boron removal due to the trapped hydroxide ions in the feed solution allowing boron to remain the negatively charged form and be transferred out of the feed solution through anion exchange membrane (AEM) [22]. However, the boron removal in DD is generally slow, limited by a driving force of concentration gradient.

$\mathrm{O}_{2}+2 \mathrm{H}_{2} \mathrm{O}+4 e^{-} \rightarrow 4 \mathrm{OH}^{-}$

To overcome the limitation of concentration-gradient driven boron removal, a new strategy was proposed in this study to remove boron driven by electrical field in an MFC with AEM separating its anode and cathode compartments. In such an MFC, the oxygen reduction reaction on its cathode produces hydroxide ions, resulting in high $\mathrm{pH}$ that transforms boric acid into borate ions. The electrical field drives the movement of chloride ions, borate ions, or other abundant anions in the catholyte across the AEM into the anode compartment (Fig. 1). Such current driven borate removal is expected to surpass the passive movement of borate in the previously reported MDC-Donnan Dialysis system.
The objectives of this study were to 1 ) examine the feasibility of using an MFC to remove boron under either the pretreatment or post-treatment mode; 2) evaluate the effect of current generation on boron removal; and 3) investigate the salinity change during boron removal.

\section{Materials and methods}

\subsection{MFC setup}

The MFC was constructed as a tubular reactor consisting of one layer of anion exchange membrane (AEM, AMI-7001, Membrane International, Inc., Glen Rock, NJ, USA) with a diameter of $3.8 \mathrm{~cm}$ and a length of $32 \mathrm{~cm}$, making the anode compartment volume of $350 \mathrm{~mL}$. The top and bottom of the reactor were sealed by PVC caps, on which the effluent and influent connectors were installed. The anode electrode was a piece of carbon cloth (with effective surface dimensions of $22 \mathrm{~cm}$-long and $2.9 \mathrm{~cm}$-diameter) installed alongside the inner surface of the AEM tube and supported by a plastic mesh. The cathode electrode was a piece of carbon cloth that was coated with activated carbon supported platinum ( $\mathrm{Pt} / \mathrm{C}$ ) as a catalyst at a loading rate of $0.3 \mathrm{mg} \mathrm{Pt} \mathrm{cm}{ }^{-2}$ and wrapped outside of the AEM tube. An external resistor of 10 or $1 \Omega$ connected the two electrodes by using titanium wire.

\subsection{MFC operation}

The MFC was operated at a room temperature of $\sim 22^{\circ} \mathrm{C}$. The anode was inoculated with a mixture of aerobic and anaerobic sludge from the Peppers Ferry Regional Wastewater Treatment Plant (Radford, VA, USA). The anode feed solution was fed in a continuous mode at a rate of $0.13 \mathrm{~mL} \mathrm{~min}^{-1}$ (HRT of $1.9 \mathrm{~d}$ ), containing (per L of tap water): $\mathrm{NaAc}, 3 \mathrm{~g}$ (to ensure sufficient substrate supply); $\mathrm{NH}_{4} \mathrm{Cl}, 0.15 \mathrm{~g} ; \mathrm{NaCl}$, 0.500 g; $\mathrm{MgSO}_{4}, 0.015 \mathrm{~g} ; \mathrm{CaCl}_{2}, 0.02 \mathrm{~g} ; \mathrm{KH}_{2} \mathrm{PO}_{4}, 0.53 \mathrm{~g}$; and $\mathrm{K}_{2} \mathrm{HPO}_{4}$, $1.07 \mathrm{~g}$. The catholyte was recirculated from a container that had a volume of $200 \mathrm{~mL}$, and was dripping from the top to the bottom of the tube for rinsing the cathode electrode at a recirculation rate of $35 \mathrm{~mL} \mathrm{~min}{ }^{-1}$. The catholyte was prepared by dissolving sodium chloride and boric acid in tap water to represent four types of solutions: seawater in the pretreatment mode contained (per L of tap water) $\mathrm{NaCl}$, $35 \mathrm{~g}$ and $\mathrm{H}_{3} \mathrm{BO}_{3}, 28 \mathrm{mg}$; seawater in the post-treatment mode contained (per L of tap water) $\mathrm{H}_{3} \mathrm{BO}_{3}, 28 \mathrm{mg}$; brackish water in the pretreatment mode contained (per L of tap water) $\mathrm{NaCl}, 6 \mathrm{~g}$ and $\mathrm{H}_{3} \mathrm{BO}_{3}, 28$ or $112 \mathrm{mg}$; and brackish water in the post-treatment mode contained (per $\mathrm{L}$ of tap water) $\mathrm{H}_{3} \mathrm{BO}_{3}, 28$ or $112 \mathrm{mg}$. The prepared solutions have $5 \mathrm{mg} \mathrm{L}^{-1} \mathrm{~B}$ in seawater and 5 or $20 \mathrm{mg} \mathrm{L}^{-1} \mathrm{~B}$ in brackish water.

\subsection{Measurement and analysis}

The MFC voltage was recorded every 3 min using a digital multimeter (Keithley Instruments, Inc., Cleveland, OH, USA). The conductivity of the salt solution was measured using a benchtop conductivity meter (Mettler-Toledo, Columbus, OH, USA). The $\mathrm{pH}$ was measured by a benchtop pH meter (Oakton Instruments, USA). The boron concentration was measured by using the Carmine method (HACH Co., Ltd. USA, method 10252). The ion compositions in the solution were measured using ion chromatography (Dionex DX-500) with suppressed conductivity detection. The column used for cations was a CS-16 with a CSRS-300 suppressor and for anions was an AS-9HC with an ASRS300 suppressor. The current density was normalized by the volume of the anode compartment. The boron removal rate was calculated as the amount of boron removed from the catholyte within the treatment time normalized by the AEM area:

$r_{B}=\frac{\left(C_{0}-C_{t}\right) \times V}{A \times t}$

where $C_{0}$ is the initial boron concentration in the catholyte, $C_{t}$ is the 


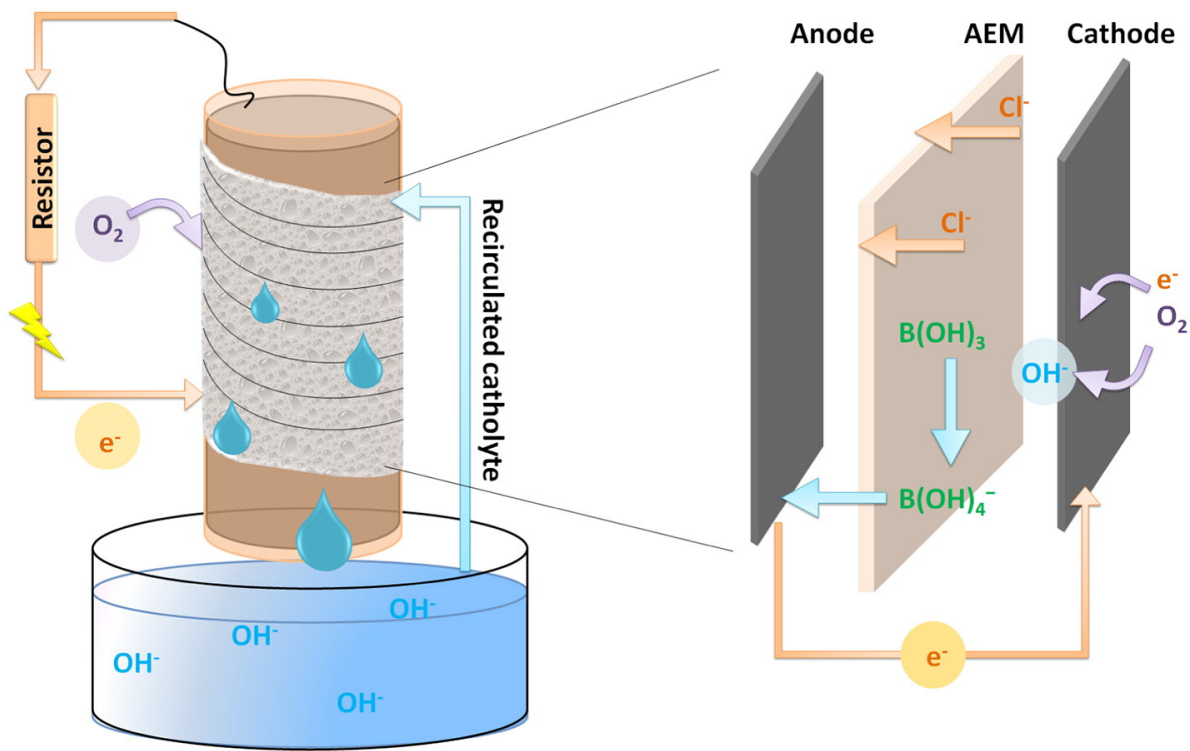

Fig. 1. Schematic of a microbial fuel cell treating boron containing salt solution.

boron concentration at time $\mathrm{t}, V$ is the volume of the catholyte, $A$ is the membrane surface area of the AEM, and $t$ is the time length of the treatment.

\section{Results and discussion}

\subsection{Boron removal from seawater}

The feasibility of boron removal by the MFC was firstly examined with artificial seawater that contained $5 \mathrm{mg} \mathrm{B} \mathrm{L}^{-1}$. The experiments were conducted under two scenarios: the pretreatment mode that the MFC is assumed to treat original seawater followed by further desalination (which was not included in this study), and the post-treatment mode that the MFC receives the desalinated seawater. Meanwhile, the effect of current generation on boron removal was investigated by adjusting the external resistance load ( 10 and $1 \Omega$ ). In both modes, the $\mathrm{pH}$ of the catholyte was increased higher than 9.14 within $4 \mathrm{~h}$ due to oxygen reduction reaction, which rendered borate ions to be the dominant boron species. In the pretreatment mode, the MFC reduced the boron concentration from 5 to $3 \mathrm{mg} \mathrm{B} \mathrm{L}^{-1}$ (Fig. 2A), which is above the irrigation standard or the WHO guideline value. Higher current generation at $1 \Omega\left(67.8 \pm 33.2 \mathrm{~A} \mathrm{~m}^{-3}\right)$ than that at $10 \Omega(45.5 \pm$ $14.0 \mathrm{~A} \mathrm{~m}^{-3}$ ) did not obviously improve boron removal, likely because that the high concentration of chloride ions in the catholyte outcompeted the borate ions during anion transport across the AEM. On the other hand, the post-treatment mode exhibited effective removal of boron. At $10 \Omega$, the MFC generated $48.7 \pm 1.1 \mathrm{~A} \mathrm{~m}^{-3}$ (Fig. 2B), slightly higher than that of the pretreatment mode, and decreased the boron concentration from 5 to $2 \mathrm{mg} \mathrm{L}^{-1}$. Decreasing the external resistance to $1 \Omega$ improved the current generation to $81.0 \pm 1.2 \mathrm{~A} \mathrm{~m}^{-3}$, resulting in an even lower boron concentration of $1 \mathrm{mg} \mathrm{L}^{-1}$ (Fig. 2A). The boron removal rate of $0.31 \mu \mathrm{g} \mathrm{m}^{-2} \mathrm{~s}^{-1}$ was observed during the first $8 \mathrm{~h}$ with $10 \Omega$. When switching to $1 \Omega$, because of a stronger driving force due to higher current generation, the borate removal rate across the AEM was improved to a higher level, resulting in a much higher boron removal rate of $0.98 \mu \mathrm{g} \mathrm{m}^{-2} \mathrm{~s}^{-1}$ during the first $8 \mathrm{~h}$.

It is worth noting that the migration of chloride ions from the catholyte into the anolyte largely influenced the microbial community and thus the current generation in the pretreatment mode. Upon supplying the synthetic seawater to the MFC cathode, an instant current increase to $72 \mathrm{~A} \mathrm{~m}^{-3}$ was observed due to the reduced electrolyte resistance (seawater conductivity of $51.60 \mathrm{mS} \mathrm{cm}^{-1}$ compared with tap water at $0.15 \mathrm{mS} \mathrm{cm}^{-1}$ ) and followed by constant current decrease to around $30 \mathrm{~A} \mathrm{~m}^{-3}$, lower than $49 \mathrm{~A} \mathrm{~m}^{-3}$ from the MFC with the tap water catholyte (Fig. 3). Because the MFC was inoculated with nonhalophile bacteria from wastewater, which would survive with a $\mathrm{NaCl}$ concentration lower than $12.9 \mathrm{~g} \mathrm{~L}^{-1}[23,24]$, intrusion of chloride ions from the catholyte into the anolyte could damage the anode microbial activity, thereby affecting electricity generation. Such an inhibitory effect could be alleviated by decreasing the salt input to the catholyte (e.g., slow down its flow rate), or increasing the anolyte flow rate for
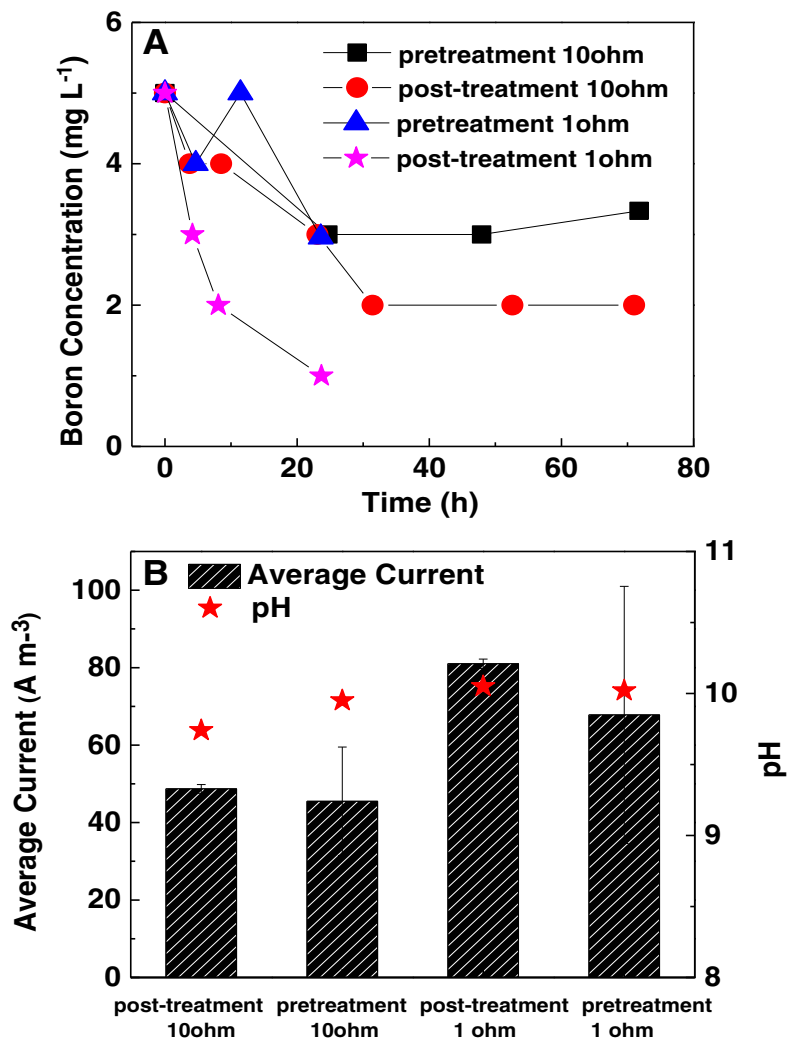

Fig. 2. The MFC performance of treating boron containing seawater: (A) boron concentration in the catholyte; and (B) the average current densities and the $\mathrm{pH}$ of the catholyte after one day treatment. 


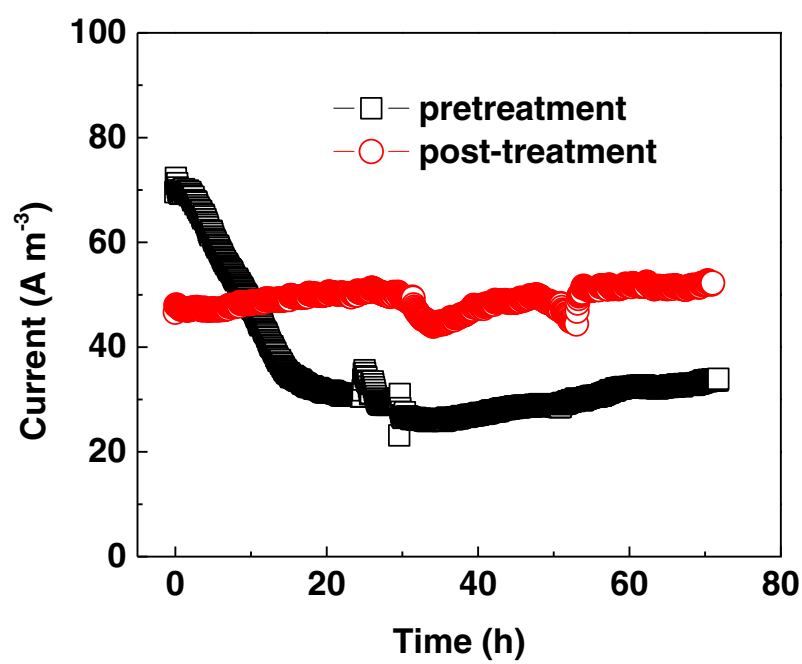

Fig. 3. The current generation by the MFC in the pretreatment and post-treatment modes.

more dilution effect. The detailed analysis of transport of chloride ions will be discussed in Section 3.3. Despite higher current generation of the pretreatment mode in the first few hours, the total electrical charge (coulomb) of the pretreatment mode within one day was lower than that of the post-treatment mode. However, the $\mathrm{pH}$ of the catholyte under the pretreatment mode was comparable or even higher than that in the post-treatment mode (Fig. 2B). By dividing the amount of retained hydroxide ions in the catholyte (converted from $\mathrm{pH}$ value) over the theoretical production of hydroxide ions based on current generation, a ratio of 0.0007 or 0.0018 was obtained for the pretreatment mode with $10 \Omega$ or $1 \Omega$, higher than 0.0004 or 0.0007 in the post-treatment mode, indicating that the extent of hydroxide ion migration across the AEM in the post-treatment mode could be greater than that in the pretreatment mode. Because the ionic transport rate is closely correlated with ion concentration [25], chloride ions were most responsible for the ionic transport across the AEM in the pretreatment mode due to its greater concentration, and hindered the transport of both hydroxide and borate ions.

\subsection{Boron removal from brackish water}

Boron removal by the MFC was further investigated with brackish water containing either 5 or $20 \mathrm{mg} \mathrm{L}^{-1}$ of boron ( 28 or $113 \mathrm{mg} \mathrm{L}^{-1}$ boric acid); 1-ohm external resistance was used in the electrical circuit for high current generation. Like the seawater experiments, the posttreatment mode achieved better boron removal than the pretreatment mode. When operated in the pretreatment mode, the MFC reduced the boron concentration from 19 to $10 \mathrm{mg} \mathrm{L}^{-1}$ at a removal rate of $4.40 \mu \mathrm{g} \mathrm{m}^{-2} \mathrm{~s}^{-1}$ or from 4.0 to $2.3 \mathrm{mg} \mathrm{L}^{-1}$ at a rate of $0.73 \mu \mathrm{g} \mathrm{m}^{-2} \mathrm{~s}^{-1}$ during the first $3-5 \mathrm{~h}$; no further removal was observed afterwards (Fig. 4A). In the post-treatment mode, the MFC decreased the boron from 20 to $2 \mathrm{mg} \mathrm{L}^{-1}$, or 5 to $1 \mathrm{mg} \mathrm{L}^{-1}$ within one day, both of which were below the required concentration for irrigation or WHO (World Health Organization) regulation. The post-treatment mode also achieved a high removal rate of $6.25 \mu \mathrm{g} \mathrm{m} \mathrm{m}^{-2} \mathrm{~s}^{-1}$ during the first $4 \mathrm{~h}$ with an initial $20 \mathrm{mg} \mathrm{L}^{-1}$. The MFC generated a much higher current density of $115.6 \pm 3.7 \mathrm{~A} \mathrm{~m}^{-3}$ in the pretreatment mode than that of the post-treatment mode $\left(84.0 \pm 4.4 \mathrm{~A} \mathrm{~m}^{-3}\right)$, due to the higher catholyte conductivity $\left(6.18 \pm 0.18 \mathrm{mS} \mathrm{cm}^{-1}\right.$ vs. $0.27 \pm$ $0.03 \mathrm{mS} \mathrm{cm}^{-1}$ ); however, the hindrance of the high salinity in the pretreatment mode towards the removal of borate ions was also obvious. Higher current generation led to higher $\mathrm{pH}$ of $10.58 \pm 0.08$ in the salt solution in the pretreatment mode compared with $10.10 \pm 0.08$ of the
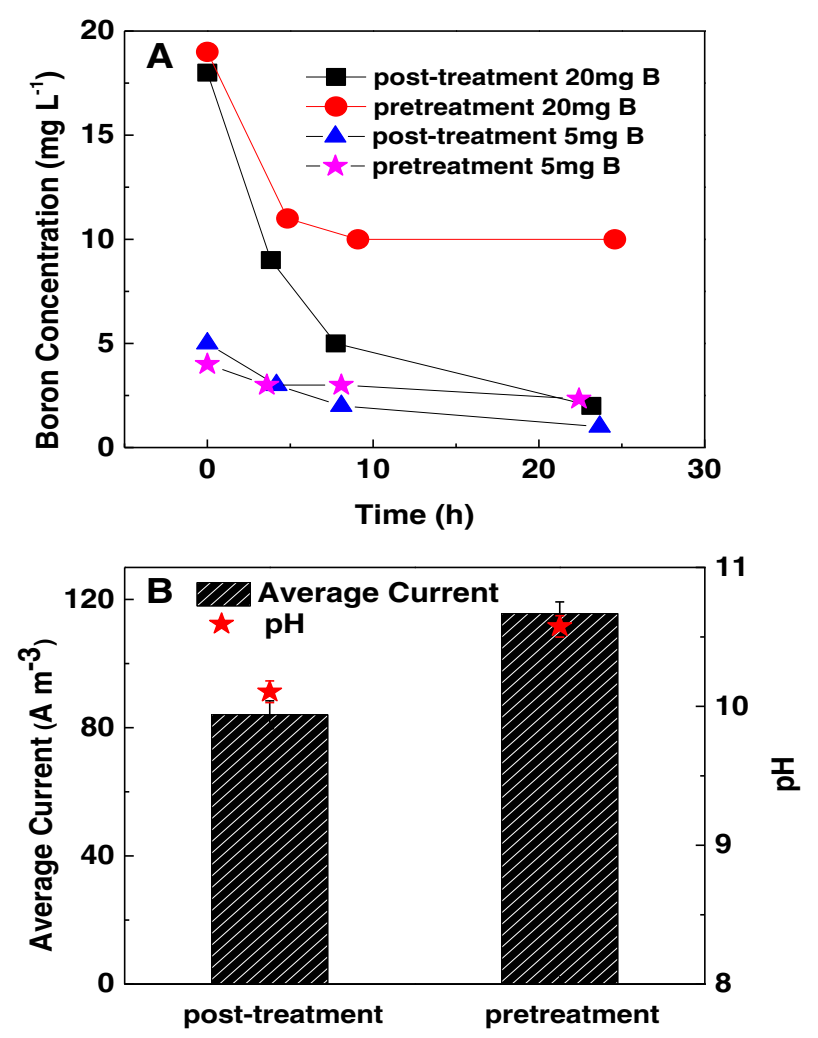

Fig. 4. The MFC performance of treating boron containing brackish: (A) boron concentration in the catholyte; and (B) the average current densities and $\mathrm{pH}$ of the catholyte after the treatment in pretreatment and post-treatment modes.

post-treatment mode (Fig. 4B). The ratio between the amount of retained hydroxide ions in the catholyte (converted from $\mathrm{pH}$ value) and the calculated production of hydroxide ions based on current generation was 0.0038 for the pretreatment mode, which is higher than 0.0018 in the post-treatment mode, suggesting that the extent of hydroxide ions migration was lower in the pretreatment mode due to the competitor ions such as chloride ions. However, the microbial community on the anode might not be negatively affected by the migrated chloride ions from the catholyte, indicated by the stable current generation of $115.6 \pm 3.7 \mathrm{~A} \mathrm{~m}^{-3}$. This was likely due to the lower salinity of the brackish water.

To further understand the contribution of boric acid diffusion and current-driven migration of borate ions to boral removal, the control experiments operated with open circuit (OC) were conducted for the posttreatment mode. The MFC with OC achieved 55-60\% boron removal for initial 20 or $5 \mathrm{mg} \mathrm{B} \mathrm{L}^{-1}$ in $24 \mathrm{~h}$, while the similar removal efficiency was obtained in the MFC with electricity generation ( $1 \Omega$ external resistance) in 4 or $8 \mathrm{~h}$. The removal rate of the MFC under OC was 1.13 or $0.36 \mu \mathrm{g} \mathrm{m}^{-2} \mathrm{~s}^{-1}$, much lower than 6.25 or $0.98 \mu \mathrm{g} \mathrm{m}^{-2} \mathrm{~s}^{-1}$ with $1 \Omega$ electrical connection (Fig. 5). In the absence of electricity generation, there was no production of hydroxide ions in the catholyte, and as a result, the $\mathrm{pH}$ of the catholyte was around $8.32 \pm 0.01$, below the pKa value of boric acid. With electricity generation, the $\mathrm{pH}$ of the catholyte could reach 9.55-10.16. It was conjectured that the water movement dragged boric acid out of the catholyte via convective transport, based on the facts that 1) the majority of boron remained in the uncharged form during the OC operation and thus ion exchange would not be effective; 2 ) water osmosis from the catholyte into the anolyte reached approximately $10 \mathrm{~mL}$ within one day; and 3) the trigonal structured boric acid has a small size close to water molecule. This presumption was confirmed with the experiments conducted in a Donnan Dialysis device equipped with AEM and neutral $\mathrm{pH}$ of the feed and strip solutions, where strong osmosis from the boron containing solution led to 


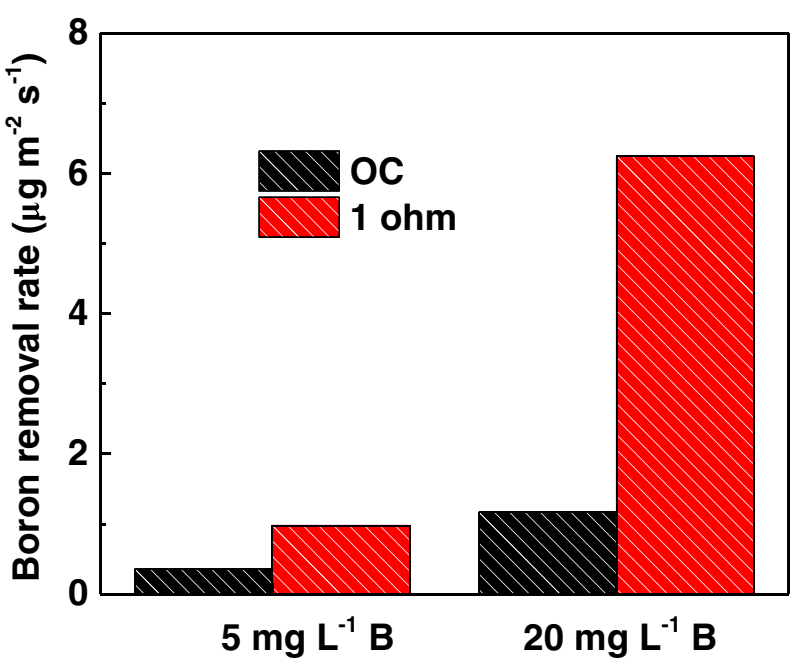

Fig. 5. The boron removal rate under the open circuit $(\mathrm{OC})$ condition and electricitygenerating condition (with $1 \Omega$ external resistance) in the post-treatment mode.

boron movement in the same direction $(50 \mathrm{~mL}$ water movement coupled with $31 \mathrm{mg}$ boric acid).

\subsection{Conductivity variation}

The conductivity of the catholyte exhibited different profiles under the two operational modes. In the post-treatment mode, the catholyte conductivity increased from 0.15 to $0.31 \mathrm{mS} \mathrm{cm}^{-1}$ with $10 \Omega$, or to $0.27 \mathrm{mS} \mathrm{cm}^{-1}$ with $1 \Omega$ (Fig. 6A). Despite this increase, the final conductivity of the catholyte (or the product water) is still below the non-restriction guideline for surface irrigation [26]. The increase was mainly caused by diffusion of $\mathrm{Na}^{+}, \mathrm{K}^{+}$, and $\mathrm{PO}_{4}^{3-}$ from the anolyte and the generated $\mathrm{OH}^{-}$. At $1 \Omega$, the highest concentration of $\mathrm{Na}^{+}$in the catholyte was $46.1 \mathrm{mg} \mathrm{L}^{-1}$ followed by $\mathrm{K}^{+}$of $7.0 \mathrm{mg} \mathrm{L}^{-1}$ and $\mathrm{PO}_{4}^{3-}$ of $2.1 \mathrm{mg} \mathrm{L}^{-1}$ (Fig. 6B). Because the industrially manufactured AEM usually does not have $100 \%$ permselectivity, it is possible that $\mathrm{Na}^{+}$ions were driven by an electrical field to cross AEM and make up for the slow anion transport due to insufficient anion supply in the catholyte. The reduction of $\mathrm{Cl}^{-}, \mathrm{NO}_{3}^{-}$, and $\mathrm{SO}_{4}^{2-}$ from $24.8,1.0$, and $5.4 \mathrm{mg} \mathrm{L}^{-1}$ to $12.0,0.0$, and $0.0 \mathrm{mg} \mathrm{L}^{-1}$ was observed in the post-treatment mode, possibly being transported into the anolyte driven by the electrical field (Fig. 6C). The disappearance of $3.7 \mathrm{mg} \mathrm{L}^{-1} \mathrm{Ca}^{2+}$ was likely due to precipitation of $\mathrm{Ca}(\mathrm{OH})_{2}$.

In the pretreatment mode, the salinity of the product water (catholyte) decreased from $10.14 \pm 0.13$ to $6.18 \pm 0.18 \mathrm{mS} \mathrm{cm}^{-1}$ for brackish water, and more dramatically from $51.60 \pm 0.28$ to $21.30 \pm$ $0.00 \mathrm{mS} \mathrm{cm}^{-1}$ for seawater (Fig. 6A). According to the results of the IC test for ion concentrations, the declined salinity was mainly caused by the reduction of both $\mathrm{Na}^{+}$and $\mathrm{Cl}^{-}$concentrations. For example, when seawater was used as a catholyte, $80.7 \mathrm{mmol}$ of $\mathrm{Na}^{+}$and $88.5 \mathrm{mmol}$ of $\mathrm{Cl}^{-}$were transported from the catholyte into the anolyte within one day, reducing the $\mathrm{Na}^{+}$and $\mathrm{Cl}^{-}$concentrations in the catholyte from

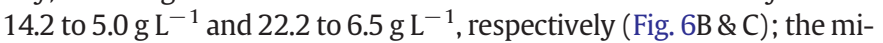
grated $\mathrm{Na}^{+}$and $\mathrm{Cl}^{-}$raised the anolyte conductivity from 6.31 to $7.28 \mathrm{mS} \mathrm{cm}^{-1}$. It is unusual that the $\mathrm{Na}^{+}$ions were transported across the AEM at such a high level, which could be related to the non-ideal permselectivity of the particular AEM used in this study. The appearance of $\mathrm{PO}_{4}^{3-}$ in the product water in both the pretreatment and the posttreatment modes was due to the diffusion of phosphate ions from the anolyte that had a high concentration of phosphate buffer (95 mg P $\left.\mathrm{L}^{-1}\right)$; this would not be an issue for real-world practice because the phosphate is typically below $10 \mathrm{mg} \mathrm{P} \mathrm{L}^{-1}$ in domestic wastewater and many industrial wastewater [27].
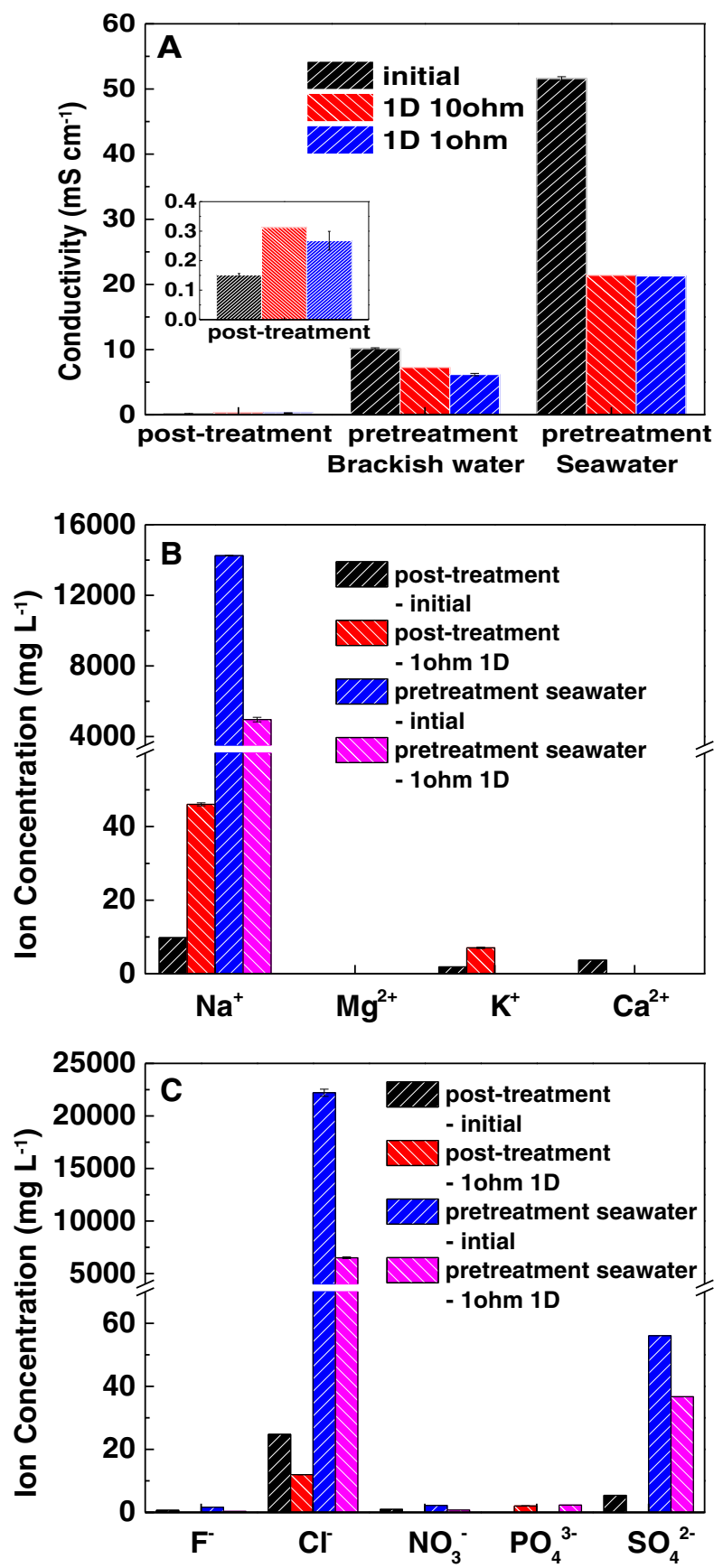

Fig. 6. Conducitivity change in the MFC cathode:(A) the conductivity of product water; (B) the concentrations of cations; and $(\mathrm{C})$ the concentrations of anions in the product water.

\subsection{Perspectives}

The MFC with AEM as a separator between the anode and the cathode compartments could be a promising approach to treat boron containing saline water and reduce the boron concentration for irrigation purpose. The simple one-membrane tubular MFC is easy to construct and maintain compared with the MDC which has two membranes. In addition to that, the MFC has achieved much higher boron removal rates than that of a previously reported MDC-DD system $\left(0.34 \mu \mathrm{g} \mathrm{m}^{-2} \mathrm{~s}^{-1}\right.$ at $1.7 \mathrm{~d}$ HRT) [22]. In the post-treatment mode, the MFC achieved a boron removal rate as high as $6.25 \mu \mathrm{g} \mathrm{m} \mathrm{m}^{-2} \mathrm{~s}^{-1}$ (within $4 \mathrm{~h}$ ), 10 times higher than that of the MDC-DD. Such improvement was benefited from active transport of borate ions driven by current 
generation, rather than the passive movement depending on the hydroxide migration in the DD to achieve charge balance. The boron concentration in the product water could meet the irrigation requirement as well as the WHO standards. One potential problem of this approach is the high $\mathrm{pH}$ of the product water, which would require further adjustment.

Although the pretreatment mode did not achieve a low concentration of boron with either brackish water or seawater, the MFC raised the $\mathrm{pH}$ of seawater or brackish water up to 10.60 , which could potentially improve boron removal in the following desalination (e.g., by RO). In addition, the MFC greatly reduced the conductivity of saline water through electricity-driven transport of $\mathrm{Cl}^{-}$and diffusion of $\mathrm{Na}^{+}$across the AEM, which could benefit the following desalination. The intense salt/ion transport could lead to inhibition on the anodic bacteria, but the problem can be alleviated by adapting microbial community in response to increased salinity and/or by adjusting the anolyte retention time. The $\mathrm{pH}$ increase in the MFC avoids addition of chemicals, which will benefit the downstream desalination and save the operating expenses.

\section{Conclusions}

This study has demonstrated the feasibility of using MFC to enhance boron removal by electricity generation. The oxygen reduction reaction serves as an effective method to raise the $\mathrm{pH}$ of saline solution and ionize boric acid to borate ions. Both pretreatment and post-treatment modes achieved boron removal while the post-treatment mode was able to reduce boron concentration to meet requirement for irrigation or municipal use. In addition to the electrical current driving force exerted on borate ions, convective transport of boric acid with water osmosis also contributed to the migration of boron species. During boron removal, the MFC greatly decreased the conductivity of artificial seawater through both current-driven migration of chloride ions and diffusion of salt. Further development of MFCs for boron removal will need to consider continuous operation and examine long term performance.

\section{Acknowledgments}

This work was made possible by NPRP grant \# 6-289-2-125 from the Qatar National Research Fund (a member of Qatar Foundation). The statements made herein are solely the responsibility of the authors.

\section{References}

[1] E. Mathioulakis, V. Belessiotis, E. Delyannis, Desalination by using alternative energy: review and state-of-the-art, Desalination 203 (2007) 346-365.

[2] L. Melnik, O. Vysotskaja, B. Kornilovich, Boron behavior during desalination of sea and underground water by electrodialysis, Desalination 124 (1999) 125-130.

[3] E. Guler, C. Kaya, N. Kabay, M. Arda, Boron removal from seawater: state-of-the-art review, Desalination 356 (2015) 85-93.
[4] N. Kabay, M. Bryjak, Boron removal from seawater using reverse osmosis integrated processes A2 - Hilal, Nalan KabayMarek BryjakNidal, Boron Separation Processes, Elsevier, Amsterdam 2015, pp. 219-235 (Chapter 9).

[5] E. Guler, D. Ozakdag, M. Arda, M. Yuksel, N. Kabay, Effect of temperature on seawater desalination-water quality analyses for desalinated seawater for its use as drinking and irrigation water, Environ. Geochem. Health 32 (2010) 335-339.

[6] U.S. Department of the Interior Bureau of Reclamation, Boron rejection by reverse osmosis membranes: national reconnaissance and mechanism study, Desalination and Water Purification Research and Development Program Report No. 127, 2009.

[7] E. Guler, J. Piekacz, D. Ozakdag, W. Kujawski, M. Arda, M. Yuksel, N. Kabay, Influence of the chosen process parameters on the efficiency of seawater desalination: SWRO pilot plant results at Urla Bay seashore, Desalin. Water Treat. 5 (2009) 167-171.

[8] N. Kabay, O. Arar, F. Acar, A. Ghazal, U. Yuksel, M. Yuksel, Removal of boron from water by electrodialysis: effect of feed characteristics and interfering ions, Desalination 223 (2008) 63-72.

[9] E. Ofir, A. Brenner, K. Muuler, V. Gitis, Boron removal from seawater by electrochemical treatment as part of water desalination, Desalin. Water Treat. 31 (2011) 102-106.

[10] M. Kijanski, B. Bandura-Zalska, P. Dydo, M. Turek, The concept of a system for electrodialytic boron removal into alkaline concentrate, Desalination 310 (2013) 75-80.

[11] Z. Ge, J. Li, L. Xiao, Y. Tong, Z. He, Recovery of electrical energy in microbial fuel cells, Environ. Sci. Technol. Lett. 1 (2014) 137-141.

[12] R.A. Rozendal, H.V.M. Hamelers, K. Rabaey, J. Keller, C.J.N. Buisman, Towards practical implementation of bioelectrochemical wastewater treatment, Trends Biotechnol. 26 (2008) 450-459.

[13] Z. Ge, Z. He, Long-term performance of a 200-liter modularized microbial fuel cel system treating municipal wastewater: treatment, energy, and cost, Environ. Sci. 2 (2016) 274-281.

[14] K.S. Jacobson, D.M. Drew, Z. He, Use of a liter-scale microbial desalination cell as a platform to study bioelectrochemical desalination with salt solution or artificial seawater, Environ. Sci. Technol. 45 (2011) 4652-4657.

[15] Q.Y. Ping, Z.Y. Huang, C. Dosoretz, Z. He, Integrated experimental investigation and mathematical modeling of brackish water desalination and wastewater treatment in microbial desalination cells, Water Res. 77 (2015) 13-23.

[16] B.E. Logan, D. Call, S. Cheng, H.V.M. Hamelers, T. Sleutels, A.W. Jeremiasse, R.A. Rozendal, Microbial electrolysis cells for high yield hydrogen gas production from organic matter, Environ. Sci. Technol. 42 (2008) 8630-8640.

[17] Y. Tong, Z. He, Nitrate removal from groundwater driven by electricity generation and heterotrophic denitrification in a bioelectrochemical system, J. Hazard. Mater. 262 (2013) 614-619.

[18] Y. Li, B. Zhang, M. Cheng, Y. Li, L. Hao, H. Guo, Spontaneous arsenic (III) oxidation with bioelectricity generation in single-chamber microbial fuel cells, J. Hazard. Mater. 306 (2016) 8-12.

[19] X. Wu, F. Tong, X. Yong, J. Zhou, L. Zhang, H. Jia, P. Wei, Effect of NaX zeolite-modified graphite felts on hexavalent chromium removal in biocathode microbial fuel cells, J. Hazard. Mater. 308 (2016) 303-311.

[20] B.E. Logan, K. Rabaey, Conversion of wastes into bioelectricity and chemicals by using microbial electrochemical technologies, Science 337 (2012) 686-690.

[21] S.C. Popat, D. Ki, B.E. Rittmann, C.I. Torres, Importance of OH- transport from cathodes in microbial fuel cells, ChemSusChem 5 (2012) 1071-1079.

[22] Q. Ping, I.M. Abu-Reesh, Z. He, Boron removal from saline water by a microbial desalination cell integrated with donnan dialysis, Desalination 376 (2015) 55-61.

[23] X. Wang, S. Cheng, X. Zhang, X.-y. Li, B.E. Logan, Impact of salinity on cathode catalyst performance in microbial fuel cells (MFCs), Int. J. Hydrog. Energy 36 (2011) 13900-13906.

[24] H. Liu, S.A. Cheng, B.E. Logan, Power generation in fed-batch microbial fuel cells as a function of ionic strength, temperature, and reactor configuration, Environ. Sci. Technol. 39 (2005) 5488-5493.

[25] H. Strathmann, Ion-exchange Membrane Separation Processes, Elsevier B.V, Amsterdam, 2004.

[26] R.S. Ayres, D.W. Westcot, Water Quality for Agriculture, FAO irrigation \& drainage paper, 29, Food and Agriculture Organization of the United Nations, 1985 Rome.

[27] Z. Yuan, S. Pratt, D.J. Batstone, Phosphorus recovery from wastewater through microbial processes, Curr. Opin. Biotechnol. 23 (2012) 878-883. 